\title{
Italian Transnational Spaces in Japan \\ Doing Racialised, Gendered and Sexualised Occidentalism
}

TOSHIO MIYAKE

UNIVERSITÀ CA' FOSCARI VENEZIA

-INTRODUCTION: 'JAPAN' MEETS 'ITALY'

Following the global success of the 'Made in Italy' brand in the 1980s, Japan witnessed an Italian consumer boom (Itaria bümu) in the early 1990s that turned Italy into the most loved foreign country, especially of women and young people, over the last decade. ${ }^{1}$ The recent attractiveness of Italy in Japan is arguably unparalleled around the world in its intensity and duration, but the phenomenon has gone largely unnoticed in scholarly literature. Italy's popularity relies to a large extent on how the country has been constructed as an idealised and orientalised 'West': an imagined geography resulting from an ambivalent process involving both the superiorisation of its antique or classical past (the Roman Empire, the Renaissance) and the inferiorisation of its recent past and contemporary present. It is the very configuration of Italy as a strategic interface between the hegemonic Euro-American other and the subaltern Japanese self that proves to be particularly 
seductive in the mediation of deep-rooted, unresolved and uncanny tensions of proand anti-Westernism. ${ }^{2}$

However, a peculiarity in the initial formation of this imagined geography is the relatively small degree of direct and significant contributions coming from Italian institutions, corporations and migrants. At present, Italy-Japan relations are quite marginal in their overall political significance and the degree of economic exchange and migration between the two nations. So, how did this kind of simulacrum become so popular in Japan throughout the twentieth century? What (un)familiar implications might the 'Italy' made by and for others have on the experience of Italianness among Italian students, workers and migrants in contemporary Japan?

As it happens, Japan has also become increasingly attractive in Italy over the last few decades, due to the international success of its transmedial constellation of J-culture-manga, anime, video games, subcultural styles and so on. It is intriguing that this has happened without an overly strong or significant intervention from Japanese institutions, corporations or migrants. Over the last thirty years, Italy, like many other countries in the world, has witnessed its younger generations become broadly enculturated from early childhood through contact with Japanese popular cultures; it does, however, stand out for broadcasting the greatest number of television anime series outside Japan, a fact that has contributed to the configuration of Japan as a highly popular and 'cool' Far East. ${ }^{3}$

The growing popularity of Japan in Italy relies upon the conflation of modern Orientalism with postmodern techno-Orientalism, intermingling hyper-traditional icons - such as geisha, samurai and zen aesthetics-with hyper-modern icons of Japan's high-tech cityscape, mangaesque consumer culture and fashionable youth culture. As a result, Japan is understood as a cultural oxymoron, a contradictory and exciting fusion of extreme differences: East/West, tradition/modernity, nature/technique, mysticism/alienation. ${ }^{4}$ This imagined geography of Japan is also sustained, even if to a lesser extent than its Italian counterpart in Japan, by its potential to mediate tensions of identification and othering related to notions of 'the East' and 'the West'. Finally, it has induced more and more young Italians to experiment with the hybridisation of a 'Japan made in Italy' in terms of globalising culture, as well as to study Japanese or visit or work in Japan. ${ }^{5}$ 
This essay engages with the concept of the uncanny in Italy-Japan relations by considering them as configured by the broader hegemony of modern Occidentalism. ${ }^{6}$ To investigate how Italian transnational spaces in modern and contemporary Japan are invested with complex projections of un/familiarity, it focuses on the interrelational, intersectional and positional process engendered by the interaction of Occidentalism, Orientalism and self-Orientalism.

The interrelational approach highlights how imagined and emotional geographies of 'Italy' in Japan have been shaped by the asymetrical and liminal positions of both nation-states in regard to the centre of colonial and imperialist capitalism. This essay argues that it is the founding ambivalence of modern Japan and Italy as both orientalising and orientalised nation-states that has to be repressed to guarantee the reproduction of Occidentalism, something that periodically resurfaces, haunting the reassuring unity of 'the West', 'the East', 'Italy' and 'Japan'.

The intersectional approach employed here points to the intertwined and cumulative effect of multiple dimensions of identification and othering, such as civilisation, nation, class, race/ethnicity, gender, sexual orientation, on the intrasocietal level.7 This enables Occidentalism to bridge different fields of discourse, representations and emotions, ultimately resulting in the naturalisation of its effectiveness as an almost invisible hegemony.

Finally, the positional approach employed by this study provides a more spaceand time-specific perspective in order to facilitate a focus on the consumer-driven Italian boom in Japan during the 1990s. More specifically, it offers the opportunity to investigate the dis/conjunctive impact and self-reflexive potential of the othering gaze to the subjective experience of Italian young migrants in contemporary Japan in terms of whiteness, gender and sexual orientation.

—TOWARD A CRITICAL OCCIDENTALISM: INTERRELATIONALITY, INTERSECTIONALITY, POSITIONALITY

From a historical perspective, Italy and Japan share the important commonality of being latecomers in the process of the formation of modern nation-states (Italy in 1861, Japan in 1868). This results in both a relatively marginal position for each country in relation to the centre of world modernisation and an ambiguous status with regard to the East/West divide. Both became imperialist nations in the late 
nineteenth and early twentieth centuries, imposing colonialist domination on NorthEast Africa or East Asia; but they have also both been ultimately subordinated to more powerful nation-states, such as Great Britain, Germany or the United States. Both countries have undergone the process of modern nation building as an imagined community without being either fully hegemonic or subaltern, or completely 'Western' or 'Eastern'. In other words, Italy and Japan share a liminal position, having been agents in the recent past of orientalistic othering in terms of race/ethnicity, gender, class, and so on through the colonisation of subaltern regions and peoples on the one hand, but also because they have been objects of the very same Orientalism imposed upon them by more hegemonic nation-states on the other. Accordingly, it can be argued that modern national identity in Italy and Japan, and especially its dispersion over transnational spaces, has been shaped by a complex network of self- and hetero-representations as well as by a mutually constitutive process of asymmetrical relations within the broader imagined geography of Occidentalism.

As a constellation of discourses, practices and institutions based upon the idea of 'the West', Occidentalism has played a hegemonic role in the configuration of collective identity and alterity since the age of colonialist and imperialist capitalism. The imagined geography of 'the West' has been effective in inscribing the whole of humanity along hierarchical yet fluid lines of inclusion and exclusion, encompassing global power relations in geopolitical contexts, and knowledge practices and affective investments in geocultural spheres. In its extended sense, Occidentalism refers to every discourse, practice or emotion that contributes to shaping the very idea of the existence of something called 'the West' or 'Western', irrespective of whether these influences are pro- or anti-Western. Accordingly, Occidentalism is not limited to a simple reverse or counter Orientalism that is expressed by anti- or proWestern ideologies and used strategically to generate internal nationalism or the subversion of Euro-American colonialism. Rather, Occidentalism must be more radically understood as the precondition of Orientalism's very possibility, and it refers both to self-definition on the Euro-American side as well as to otherdefinition on the non-Euro-American side. ${ }^{8}$

The critical approach adopted in this investigation builds upon Edward Said's work on Orientalism but is mostly inspired by the notion of hegemony elaborated by 
Antonio Gramsci. ${ }^{9}$ The following passage from Gramsci's Prison Notebooks (192935) stands out for its pioneering questioning of the very concept of 'the West' as an epistemological category, as well as for the interesting suggestion that Japanese selfOrientalism is a consequence of modern Eurocentric hegemony:

The objectivity of the real. In order to understand precisely what significance this concept might have, it seems to me opportune to dwell on the example of the concepts of 'East' and 'West', which never cease to be 'objectively real' even though when analyzed they turn out to be nothing more than a 'historical' or 'conventional construct' ... It is obvious that East and West are arbitrary and conventional (historical) constructions, since (outside of real history) every spot on earth is simultaneously East and West. Japan is probably the Far East not only for the European but also for the American from California, and even for the Japanese himself, who, through English political culture, might call Egypt the Near East, which from his viewpoint should be the West, etc. Furthermore, the purely historical nature of the significance attached to these terms can be seen from the fact that the words 'East' and 'West' have now acquired supernumerary meaning and even refer to relations between whole civilizations. ${ }^{10}$

Gramsci only occasionally reflected upon the concept of a Eurocentric imagined geography, but this passage is particularly useful in the context of my essay, where its ideas are integrated with Gramsci's more fully expressed notion of hegemony as a dynamic balance of coercion and consent performed by different social groups in a historical and mutually articulated process. By applying this perspective to the international context of contact between nation-states as well as within national societies, it becomes clear that Occidentalism is reducible neither to a one-sided imperialist rule exercised by dominant and powerful actors within the broader capitalistic world order, nor to a unilateral repression suffered by those who are dominated against their own interests. Instead, Occidentalism is the highly interrelational, and even complicit, process enacted by the dominant and the subaltern sides that makes hegemony effective and ultimately leads to its reproduction even without its imposition by force. Although the transnational, transcultural and hybrid signifying practices induced by globalisation have 
intensified over the last decades, 'the West' nonetheless continues to be reproduced as an unmarked assumption-a deep-rooted, self-evident and ultimately naturalised term-that is still common in academic jargon as well as in the bridging of the public and private spheres. In this sense, borrowing from Stuart Hall's discussion of the contrast between 'inferential racism' and 'overt racism', Occidentalism too has become 'inferential' through the hegemonic mobilisation of discourses, practices and emotions in which a subtle naturalisation of unquestioned occidentalist assumptions remains largely invisible to, or even repressed by, those who deploy them. ${ }^{11}$

The key to the hegemonic effectiveness of this imagined geography is the mutual processuality of Occidentalism to both Orientalism and self-Orientalism, which can be summed up as follows. In the modern age Occidentalism has been a self-definition as 'the West', first in Europe and then in the United States, that is articulated via intertwined paradigms aimed at defining its modern identity: reason, science, progress, universalism, individualism, masculinity, the white race, adulthood and so on. Like any kind of hegemonic identity, it is not limited to an isolated or homogenous paradigm. Occidentalism relies on its ability to intersect very different axes of social-cultural identification related to nationality, class, race/ethnicity, gender, sexual orientation and age. On the intra-national level, this cumulative intersectionality is what enables Occidentalism to mobilise very different modes of representation, practice and emotion, arguably causing it to permeate every dimension of human existence, and ultimately resulting in its most effective form: self-evidence, naturalisation and, eventually, invisibility. As Said has shown, this self-definition has been configured through hierarchic contrast with an other-definition about what is or should be other to itself (Orientalism). Depending on the context and the time period, this other could be configured as 'the East', 'the Rest', 'Islam', 'Africa' or even as a single nation-state like 'Japan'. Being imagined, defined, desired or hated as fundamentally other to Euro-American modernity, this other will be, or must be, reduced to traditional paradigms such as emotionality, stasis, particularism, groupism, femininity, coloured race and so on.

The crucial point is that the employment of this identification and othering process to become hegemonic on a global scale implies more than a one-sided exercise of exoticising fantasies expressed in texts, pictures and music, or a 
unilateral imposition on the passive, mute and subaltern other sustained by military, political or economic power. The effectiveness of hegemony relies upon the hegemony's acceptance, interiorisation and active reproduction by the subaltern itself. This applies to the other-definition of 'the West' as hegemonic other (Occidentalism) as well as to self-definition as the more or less subaltern 'East' (selfOrientalism). In other words, Occidentalism becomes completely hegemonic only through its interrelation with the non-Euro-American subaltern, and only when the latter accepts the imagined geography of 'the West' as a looking-glass to make sense of themself as well as others, thereby mobilising a similar process of intersecting discourses, practices and emotions.

Occidentalism can be further rearticulated in the case of the modern nationstate of Japan as the other-definition of its colonised Asian neighbours as a subaltern 'East' (Orientalism) through the employment of a strategic hybrid of selfOccidentalism and self-Orientalism to define its own national identity as a unique (and superior) synthesis of 'the West' and 'the East'.12 Regardless of historical or regional variation, and regardless of being configured necessarily through a dualistic antithesis, interrelational dynamics between nations and intersectional mobilisation within nations have contributed jointly to the hegemonic effectiveness of Occidentalism since modern times. The result is a mutually constitutive and intersubjective process, a sort of mirror game in which specular identity and alterity representations enforce one another, reproducing 'the West' as the ultimate and universal point of reference.

Nevertheless, Occidentalism is neither a static structure nor a closed system; rather, it is a historical process whereby negotiation and disjunctions are always at stake. Its hegemonic range relies upon how the imitation, interiorisation and reproduction of its intersecting discourses, practices and emotions contribute to the corroboration of the sameness of discursive identity and alterity, or, on the contrary, are able to introduce some ambiguity, slippages or even subversive disruptions. Hegemony is an intrinsically polyphonic process. Thus, the liminal positions of both Japan and Italy reveal how Occidentalism is not only a mutually constituted process shaped by a generic centre/periphery model, but more particularly is an asymmetrical network of relations articulated through multiple, nuanced and fluid positions of dominance and subalternity. 
This preliminary discussion of the interrelational and intersectional processuality of hegemony has focused on the broader geopolitical and geocultural frame of modern Occidentalism. The additional focus on positionality in the discussion that follows will provide a more contingent perspective particularly suited to the specific cases of Japan and Italy. Positionality in terms of the imagined geography of Italy in Japan will be employed in a diachronic sense, first to concentrate on the resulting effect of an already given process of asymmetrical relations, and second, to address the generative potential of change embedded in the space- and time-specific experience of individual subjectivity.

- IMAGINED GeOgRAPHIES OF ITALY IN MODERN JAPAN

What gives the majority of Japanese the characteristic image of Japanese culture, is still its distinction from the so-called West ... The loss of the distinction between the West and Japan would result in the loss of Japanese identity in general. ${ }^{13}$

How does the imagined geography of Italy fit within the broader process of the interaction of Occidentalism, Orientalism and self-Orientalism in Japan? What kind of strategic advantages is 'Italy' able to mobilise with regard to tensions of identification and othering? In reality, the idea of Italy has had a marginal role in the articulation of the notion of 'the West' in modern Japan, which has been modelled mainly on Great Britain, Germany, France and the United States. ${ }^{14}$ This is partly because of the limited contact between Japan and Italy, except during the brief military alliance of the Tripartite Pact during World War II. But it is also a consequence of the very interiorisation of the hegemonic gaze of European Occidentalism, which had already defined Italy as a southern and less developed country compared to the nation-states considered to define the paradigm of European modernity. ${ }^{15}$

In many ways, this idea of Italy is rooted in the representations diffused by central and northern European literary and artistic traditions as a consequence of the established experience of the Grand Tour. ${ }^{16}$ The alluring image of the bel paese is framed through an emphasis of its pre-modern aspects: ancient Rome, Renaissance art, beautiful landscapes and a spontaneous and cheerful people. But for the very same reason, nineteenth-century Italy could be dismissed through an emphasis on 
its apparent non-modernity: a lack of industrialisation, rationality, efficiency and other such characteristics. Looking at the first accounts of Italy by Japanese travellers in the late nineteenth and early twentieth century, it is revealing how their gaze was already framed by English, French and German perspectives, but never directly by Italian texts.

The following is a passage from the diary of Natsume Sōseki (1867-1916), the most acclaimed modern Japanese writer, who went to London in the early twentieth century to study English literature:

I thought I saw a short and peculiarly ugly man coming toward me along the street, only to realise that it was myself, reflected in a mirror [of a shop]. It has only been since coming to this place that I realised we really are yellow (London, 5 January 1901).17

This diary entry exposes in the clearest way the hegemonic mirror of 'the West' as a device of ambiguous inscription: superiorising modernisation as well as inferiorising racialisation. It is this basic ambivalence of being configured as a modern but yellow nation that would haunt the dilemma of modernisation in Japan throughout the first half of the twentieth century, from unsuccessful governmental attempts to be recognised as a world power with equal racial status, to scholars elaborating theories of Caucasian origins for the Japanese people. ${ }^{18}$ Since then, 'the West' has become progressively the most familiar other imaginable, especially in its postwar American version. But this increasing familiarity, conflated with more hybrid versions of national identity-such as Japan being the best mixture of 'the West' and 'the East' - is possible only to the extent of reassuring the removal or repression of its founding ambivalence. It is no surprise that even a century later this uncanny inscription continues to resurface and be addressed as a generative principle by leading figures of contemporary Japanese culture. ${ }^{19}$

Returning to Sōseki, what makes his diary so interesting is not only the spatialised experience of his embodied exposition to the 'Western' mirror, but also its diachronic relation to his Italian experience, which reveals another paradigmatic configuration in modern Japan: Italy as an orientalised (or orientalisable) 'West'. Before arriving in London, Sōseki passed through Italy, where he appreciated classical architecture and museums in Naples and Genoa in accordance with the Grand Tour paradigm. However, it is very revealing that at this stage he described 
the Italian passengers travelling with him on a train from Turin as 'hairy barbarians' (ketōjin): 'I spent a good deal of time wandering around in a daze, led by the porter. In the end I squeezed in among some hairy barbarians (Turin, 20 October 1900)'.20

Just two months later, the English looking-glass self would induce him to see himself as short, yellow and ugly. This shift also demonstrates the different effects caused by the Italian mirror. The term he uses to describe the Italian passengers is ketōjin, literally 'hairy Tang people', a derogatory term for Chinese and other Asian people which became common after the subjection of the Chinese Empire to British colonialism and its defeat by Japan in the Sino-Japanese War of 1894-95. In reality, during the transition from the feudal Tokugawa regime to the modern nation-state in the mid nineteenth century, the term was initially also applied to all EuroAmericans, but its use became more and more restricted over the course of the twentieth century. The crucial point here is that the increasing Orientalisation of China-which had been the overwhelmingly superiorised other in the cultural history of Japan for more than a millennium - has been transposed to Italy, at least in a lexical sense.

The limited Japanese interest in Italy, mediated mainly by English, German and American resources and perspectives, continued-except during the brief military alliance of the Tripartite Pact-almost unchanged until recent years. Since World War II there has been an increase in direct contact with Italy, scholars of Italy and students of the Italian language, as well as in the range of interests regarding Italy. However, the prevailing notion of Italy has remained very ambivalent: Italy is configured as superior because it is 'Western' and because of the riches of its cultural past (the Roman Empire, Christianity, Humanism, art), but also as inferior because of a presumed prevalence of pre-modern characteristics in comparison with Japanese standards of modernity (the mafia, corruption, political instability, economic inefficiency and so on). Even in 1986, a general survey conducted by Dime, a magazine targeting young Japanese businessmen, declared that its participants had voted Italians as the stupidest people in the world. The reasons for this were that they were too euphoric; they were always going on strike; the women were ugly and the men were always chasing girls and eating, but never working. ${ }^{21}$

Twenty years later, in 2006, a more positive image emerged from a comparative national survey commissioned by the Italian Chamber of Commerce in 
Japan. Compared to other 'Westerners' (Americans, English, Germans, French and Spanish), Italians are now considered the kindest, most creative and sexiest, even if also the most emotive and irresponsible, thereby making Italy the place, other than Japan, where most Japanese would like to live.22 In 2008, according to another national survey carried out by Japan's NHK (the public broadcasting organisation) about the most-loved countries around the world, Italy was second only to Australia, rising from twelfth place in 1983. What is more, Italy is the most-loved nation among female and young respondents, a fact that underlines the specificity of the country's popularity in terms of gender and age. ${ }^{23}$ At present, consumer analyses continue to identify Italy as the most attractive travel destination among all age groups and both genders. ${ }^{24}$

So what has happened since 1986 to change ideas about Italy in Japan?

\section{-THE ITALIAN BOOM OF THE 1990s}

Beginning in the early 1990s and reaching its peak around 1997-98, an explosion of popularity for all things Italian has occurred in Japan. Gastronomy, fashion, design, the Italian football league (Serie A), package holidays to Italy and interest in the Italian language have been the driving elements behind this sudden and ongoing popularity. The reasons for this phenomenon are related, as in other countries, to the success of the 'Made in Italy' brand in the 1980s, when Italian output, especially in the fields of fashion and design, excelled in international commercial competition. On the other hand, this success has reached unparalleled levels in Japan as a result of contingent intersections of specific internal conditions.

The Italian boom in Japan was initially a female, urban and mainly consumerist phenomenon. It was activated and amplified by fashion and lifestyle magazines, which play a dominant role in the creation of new trends and in the guidance of consumer choices. The magazine Hanako, a trendsetting publication in the 1990s that targeted young, metropolitan, white-collar women, had the most prominent role in marketing the first consumerist fad for Italian cuisine. In its April 1990 issue, Hanako featured tiramisù, an Italian desert that became a sort of national obsession for much of that year. This inaugurated the boom of seeing Italian food as stylish, young and informal, and contributed to the displacement of French cuisine, considered more conservative and formal, as the defining hallmark of 'Western' food 
in Japan. This primacy in the context of international cuisine is particularly relevant-in fact, the Italian boom is also often referred to as the 'Italian dining boom' (itameshi būmu) -in the light of a general trend in more frequent dining out. The sales figures of eating and drinking establishments grew from 410 billion yen in 1960 to 13,135 billion yen in 1992, making dining out the most popular leisure activity in contemporary Japan. ${ }^{25}$

Italy's sudden popularity in Japan is directly related to the restructuring of the labour market and the consequent emergence of women as workers and consumers in the 1980 s. ${ }^{26}$ Compared to male workers, the new generation of women has a great deal more autonomy in leisure time, disposable income and personal savings. The new purchasing power of young women, specifically directed at Italian productsmainly fashion, accessories and gastronomic products-was further enhanced by the dramatic rise in the strength of Japanese currency in relation to the Italian lira, which almost trebled in the early 1990s. This favourable exchange rate made package tours to Italy and shopping in Milan, Florence and Venice a very affordable and popular activity.

But the Italian boom has also extended to the male population. A passion for Italian cars as unique and exclusive products continues strongly. In spite of limited imports, models from the Fiat 500 to the Ferrari or Lamborghini are now invested with a distinctive aura not only as masterpieces of design or handicraft-like technology, but also, after the renewed success of the Formula 1 Ferrari in the late 1990s, as highly competitive sports cars. There is an even more widespread passion for Italian football. J-League, the first Japanese professional football league, was launched in 1993 with a huge marketing campaign sustained by promoters and the mass media. Previously a virtually unknown sport, football became almost as popular as established national sports like baseball and sumo in just a few years. In this period, the Italian Serie A was by far the richest football league in the world and boasted most of the world's top players. Arrigo Sacchi's AC Milan or Totò Schillaci and Roberto Baggio's Juventus Turin became models to dream about and emulate for a whole new generation of young football fans. Additional media coverage of Italy has been guaranteed by the career of the fashion-forward Japanese football player Hidetoshi Nakata, who is known as the 'Asian Beckham' and is one of the best players Japan has ever produced. Nakata rose to international stardom by playing on 
various Serie A teams based in different cities from 1998 to 2005 (Perugia, Rome, Parma, Bologna and Florence). ${ }^{27}$

Another curious aspect of the Italian boom has been the increase in popularity of Italian language lessons. This contributed to transforming Girolamo Panzetta, an Italian from Avellino who was a language instructor for an Italian language programme that aired on Japanese public television from 1991 to 2005, into a media star. He brilliantly exploited the stereotype of the Neapolitan man who is always eating pizza and pasta, as well as those of the joyful scamp and the fashion-conscious Latin lover, as a personal trademark. First, he overhauled the boring formats of television language programs, and then he deployed his popularity to become an omnipresent columnist, an author of dozens of books on Italian culture and a successful spokesperson in television commercials and magazine advertisements. This celebrity has made him the most famous Italian in Japan today apart from Leonardo da Vinci.28

The Italian boom has not only assured the increasing ubiquity of an imagined and mainly consumer-oriented geography in terms of ideas, icons, narratives and commodities, but has also triggered a proliferation of Italian-style spaces in Japanese metropolitan areas. ${ }^{29}$ Among the most spectacular are the simulations of Italian cityscapes, like the Comune Shiodome, a thirty-one-hectare multi-purpose district in Tokyo vaguely inspired by Renaissance and neoclassical architecture. ${ }^{30}$ Opened in 2007, local investors have filled this 'Italian town' (Italia machi) with Italian shops, restaurants, exhibition spaces and gardens to offer an added value of refined Italianness to the five-star hotels, business offices, television networks and residential complexes nearby.

In contrast to the slick, though quite aseptic, atmosphere of the Comune Shiodome, there is the Disneyland- or Las Vegas-like Venus Fort, an overtly kitschy combination of a theme park and a shopping mall that opened in 1999 on the waterfront of the artificial Odaiba Island in Tokyo Bay. ${ }^{31}$ The interior of the threefloor complex presents streets, squares, marble fountains and fake churches freely inspired by eighteenth-century urban and architectural styles that mimic Venice, Rome and Florence. It comprises about one hundred and sixty shops (including fashion boutiques, restaurants, cafés) mainly targeted at women and is covered by an artificial sky ceiling, which simulates a sunset every half hour. This has made 
Venus Fort not only one of the most popular shopping malls in the capital, but also an international tourist attraction. Other Japanese cities besides Tokyo have created their own more or less spectacular simulacra of Italian classical or mediaeval cityscapes over the last twenty years.

The most pervasive impact of the Italian boom in terms of spatialised experience, however, was that of its initial gastronomic impetus in the early 1990s. There are at present 17,881 Italian dining or drinking establishments (restaurants, pizzerias, coffee shops, wine bars) scattered all over Japan, with a concentration of 4,357 of them in Tokyo alone. ${ }^{32}$ Apart from the extreme variety of these places in their authenticity, style, price, menu and so on, a concentration of symbolic markers of Italianness are commonly displayed and experienced by almost every Japanese urban resident in everyday life. As in other more or less (self-)ethnicised Italian restaurants in the world, this can range from the visual impact of the Tricolore (the Italian flag), pictures or posters of Italian cities, the menu or wall text to the acoustic surroundings of Neapolitan, classical or pop music and greetings such as 'Buongiorno!', and from the material display of Italian interior design, furniture and objects to the gastronomic experience of Italian or Italian-like cuisine. ${ }^{33}$

There is no doubt the Italian boom has induced more positive evaluations of, increased information about, widespread familiarity with and sympathy toward Italians. What is still at stake is whether the modern hegemony of Italy as an orientalised 'West' has been fundamentally challenged or not. In the past, exoticism and racism have been different but ultimately inseparable sides of the same coin configured by the interrelation of Occidentalism, Orientalism and self-Orientalism. What kind of effects might this imagined geography and its related othering process have on Italians coming to Japan?

—LOST IN ITALIAN SIMULACRA: RACE, GENDER AND SEXUALITY

Sofia Coppola's film Lost in Translation (2003), starring Bill Murray and Scarlett Johansson, offers a vivid description of how Tokyo's metroscape might induce an ambivalent dialectic of excitement and repulsion, belonging and not belonging, familiarity and unfamiliarity. It exemplifies how cultural displacement experienced by a Euro-American traveller or migrant can be framed by violent oscillations between the perception of 'far Eastern' otherness (language, somatic appearance, 
customs, history) on the one hand and 'Western' sameness (infrastructures, architecture, dresses, consumerism) on the other. The imagined geography of Japan as a cultural oxymoron owes much of its strength to the possibility of being consumed as a voyeuristic spectacle from a reassuring distance. This neoOrientalism is also enacted in the film, in which, for the better part of their short stay, both American protagonists experience a caricature of Japan hampered by the comforts of the five-star Park Hyatt Tokyo Hotel, where they can overlook the whole cityscape. ${ }^{34}$ While the hotel is the refuge where both can ultimately resolve their initial estrangement in a delicate moment of intimacy, it does not completely protect them from occasional exposure to uncanny othering imposed upon them by being physically in Japan. One of the most revealing scenes is the one in which Bill Murray's character, an aged, fading Hollywood star, arrives in Tokyo to shoot a twomillion-dollar paid advertisement for a Japanese whisky company. Looking out the window of his taxi, he sees a giant image of himself smiling right back at him from a huge billboard advertising the same product.

The uncanny dislocation displayed in Lost in Translation can also be experienced by Italian travellers and migrants living in Japan, who are first defined as 'Westerners' or-to their personal displeasure-as 'Americans', and only secondly as 'Italians' ${ }^{35}$ But in contrast to the experience of the cosmopolitan, upperclass protagonists of Coppola's film, whose sojourn in Japan is brief, different experiences and emotions are induced by longer or permanent stays. In the latter case, a confrontation with the othering gaze with regard to one's own specific positionality in terms of class, race, gender and sexuality usually becomes inevitable. In 2011, there were only 2,600 registered Italian residents in Japan, a very small number compared to the 49,815 American residents, which places the Italians numerically in thirtieth place among foreigners. ${ }^{36}$ These numbers acquire further significance if confronted with the 17,881 Italian drinking and dining establishments, which include the 750 family-style Italian restaurants owned by the large Japanese chain Saizeriya. ${ }^{37}$ In other words, Italian transnational spaces are not only mainly made by Japanese capital, but also, and most importantly, for the Japanese consumer. Besides institutional sites, such as the Italian Embassy and Consulate, Chamber of Commerce and Institute of Culture, and their related events, which are limited mainly to Tokyo and Osaka, and to a lesser extent Italian 
companies' headquarters, there are no extensive or aggregating spaces of Italianness created from above. It is difficult to speak of some kind of stable Italian community even in Tokyo, not to mention something resembling a Little Italy. Most of the topography made by and for Italians is created from below and dispersed within a network of Italian-owned restaurants or bars (like the Segafredo bar in Shibuya), language schools, private apartments and nightclubs. Participation in these unstable, fluid and informal micro-spaces of national belonging is quite common for many Italians, who may continue to feel their cultural affiliation or not depending upon how their personal experience of Japan evolves over time.

The initial experience of Italian newcomers to Japan can be very exciting and trigger a boundless sense of narcissistic self-esteem, especially among young and/or middle- or lower-class migrants. An anonymous life at home in Italy as an average, underprivileged citizen or as a geeky Japan-loving nerd is magically transformed in Japan into that of a superstar in a racialised and cultural sense, regardless of class, education, gender or even physical appearance. Widespread attention is assured first of all due to the simple fact of being a 'Westerner': suddenly, countless people want to meet the white foreigner (gaijin), listen carefully to him or her (and possibly want to make conversation in American English, even if the foreigner indicates that he or she is Italian), appreciate his or her enlightening comments regarding Japan, pay compliments on his or her somatic appearance or style, and invite him or her to dine out and become friends. In addition, simply being 'Italian' may provide access to a range of ethnicity-based employment, like being a waiter or a language instructor, regardless of the possession of any kind of certified qualification or even the ability to speak Japanese.

The intensity and duration of emotional attachment to his or her whiteness and Italianness can vary considerably. It can range from a minimum degree among migrants who are highly skilled professionals (for example, scientists, engineers, technicians) that is unrelated to the Italian ethnic economy. More ambivalent attitudes are common among managers and workers involved in the fashion, gastronomy and language industries, and particularly among Japan-lovers or scholars who aim to understand Japan and be appreciated for their passion and knowledge of the country. It often reaches its highest degree among the increasing number of unskilled migrants with no proficiency in the Japanese language who 
move to Japan because of the economic promise of the Italy boom. For these migrants, whiteness and Italianness is their only cultural and symbolic capital and they often depend completely upon it to stay in Japan. ${ }^{38}$

Another defining variable, however, is gendered experience. This is best exemplified by Girolamo Panzetta, who rose from complete anonymity to become a media celebrity and marry a Japanese woman by strategically 'performing' the role of the stereotypical Italian male, thus demonstrating that this path can be the most rewarding in terms of economic, cultural and sexual capital. The correlation becomes further evident if we consider the perspectives expressed by three young, single, long-term Italian residents in Japan, chosen because they offer male, female and homosexual views.

The first individual's experience is a nostalgic and ironic recollection of the Italian boom of the 1990 s posted online by A., another former male Italian-language instructor:

Teaching only a few [Italian language] lessons was enough to live a good life. [I made] a lot of money and [had] a lot of leisure time. You might think, Great! Just a few hours of conversation in my native language with some beautiful girls, a flexible work schedule and being paid to do this allows me to live in Japan. This is paradise on earth.

Maybe it was. And you might also add to the picture that as a single person (or even when you aren't single), a teacher could put his hand in the cookie jar with incredible frequency...39

I know only one teacher who has never tried the cookies. I respect him for it, but if he is reading this, I have to say something to him: Hey dude! Maybe you should give it a try. You don't know what you're missing. Japanese cookies are the tastiest and most varied.40

'Putting one's hand in the cookie jar with incredible frequency' or appreciating Japanese 'cookies' as 'the tastiest and most varied' not only metaphorically expresses a markedly masculinist attitude, but also bears witness to the mutually reinforcing connection between the eroticised fascination with the 'yellow Japanese girl' among Italian men and the romanticised fascination with the 'white (Italian) man' among Japanese women, as well as the actual sexual contact to which this can lead. ${ }^{41}$ Furthermore, his account is a vivid translation of the interrelational 
hegemony of Occidentalism, Orientalism and self-Orientalism in terms of intersecting levels of race, gender and sexuality. In the light of its 'functional' satisfaction of both parties involved, it may not come as a surprise that this specific heterosexual conjunction is still evident in the widespread phenomenon of international couples and marriages between Italians and Japanese, something that continues to be nurtured by a (self-)Orientalising Madame Butterfly-inspired libidinal economy.

More self-reflexive aspects emerge in the second account of life in Japan offered by B., forty-four years old and another Italian teacher who, due to his homosexual orientation, might ironically even be the male Italian instructor mentioned in the web post above who has never tried Japanese 'cookies'. On his almost twenty years of experience at private language schools and the pressure to conform to Italian stereotypes of Italians, he remarks:

Of course, all Italian language classrooms are market-oriented and aim to display Italianness. This can range from the authentic reproduction of modern Italian design, furniture and objects without overt national symbolism to that of cheaper, easier and kitschier styles. In contrast to English or German language classes, many students coming to Italian classes are women who want to have an entertaining experience or meet a typical Italian man, which was especially true during the boom in the late 1990s...

The difficulty for me in the beginning was that I also had to conform to all the stereotypes on a personal level, which meant, among other things, downplaying my proficiency in Japanese. But over the course of the years I have learned to distance myself from the role that I have been playing. Despite my northern Italian origins and my pride in a serious commitment to a strong work ethic and to working efficiently, I have ended up providing an ever more professional performance of the Panzetta icon of the light-hearted, flirting southern Italian man. I came to realise that it was not necessarily a lie. After all, isn't Japan the country of masks, rituals and putting on an appropriate appearance according to different situations? ${ }^{42}$ A key aspect in distancing oneself from the dilemma of true versus false Italian identity is achieving proficiency in Japanese. Better communication skills have been 
pointed to by other interviewees as the element that empowers an individual's integration into Japanese society outside the confines of the Italian ethnic economy. But for B., too, whiteness means privileged access to Japanese 'cookies', even if this happens outside the classroom, and it represents a significant reward in his libidinal economy:

The female attraction to or fetish for the white man (gaijin akogare) is quite similar among male homosexuals in Japan. I have profited greatly from being Caucasian and taller than most of Japanese men, which means that I am associated with being strong and having a nice skin colour, a huge penis, sexual stamina, etc. My male partners love to show me off to their friends as a kind of status symbol, which is not dissimilar to how Japanese girls show off their Italian boyfriends. The difference might be that while these Japanese girls prefer Italian men to American ones because they consider them more refined, artistic and gentle, this has never been a factor in my experience with Japanese men. With regard to female homosexuality, I have noticed a very similar pattern to that of male homosexuality. The white man or woman assumes the role of the stronger or more mature member of the couple; it is rare to see things work the other way around-for instance, a tall, muscular Japanese man together with a smaller Western partner. ${ }^{43}$

On the contrary, living the 'other way around' can become very problematic for the heterosexual economy of Italian girls or women. As C., a thirty-five-year-old Italian female student of Japanese culture in Tokyo from 2001, recalls her five years' experience as follows:

For many other Italians coming to Japan, the initial exposure to all of the sudden interest in Italy can be both gratifying and amusing. In the second stage, a very common reaction is to make an effort to explain the 'truth' about or more nuanced aspects of Italy-to show that not all Italians, including myself, of course, conform to the prevailing stereotypes. But it is in this stage that the first feelings of incongruity arise. I've also met a lot of Japanese who knew so much more than I did about Italy-its music or its football—and who actually taught me a lot. This created the first moments 
of doubt about my sense of automatically knowing more about my own country than the Japanese do simply because I am Italian...

But it was not so much general stereotypes about Italy that were problematic for me. The most difficult were male stereotypes about Italian or white women. On the one hand I have been often-too often-admired for being beautiful, for being a white girl, for having a face like a statue! But on the other hand, it was very hard for me to find a Japanese boyfriend. It was not difficult to make friends, but for a long time it was virtually impossible to go beyond that. They all seemed to be afraid, to avoid physical contact, and they would never clearly explain why. It was a very frustrating sensation, one that was difficult to cope with when a person stays [in Japan] for such a long time...

Of course, this has become the favourite topic of discussion among many other Italian female friends who have shared the same frustration; [we have had] very long discussions about perceptions of us as a kind of femme fatale, a man-eating threat, that are nurtured by fears of emasculation or performance anxiety.

The most uncanny experience for me in Japan has not so much been my ambivalent and changing relationship to my Italianness, but the always haunting perception of being dislocated with regard to my womanhood. ${ }^{4}$ Reactions and manners of adaptation to the imagined geography of the Italian 'West' on the part of Italian migrants obviously vary according to the specific personality and situation of each individual (Italian couples, families with children, international marriages and so on). In this regard, further investigation addressing a more extended range of experiences as well as the intertwined relations of Italians with Japanese will be essential to achieving a more complete understanding of the complex interplay between Occidentalism, Orientalism and self-Orientalism that shapes Italian transnational spaces in contemporary Japan.

At this point, however, it can already be argued that it is the embodied and emotional experience of singles who are most exposed-and potentially open-to the dislocating effects of Japanese othering that highlights some crucial aspects induced by the intersectional and positional processuality of Occidentalism in terms of race, gender and sexuality. The dis/conjunctive effects pointed out by the three 
different voices (A., B. and C.) underscore how Italianness shaped by modern Occidentalism is neither equally distributed nor equally rewarding. But at the same time, they also imply that the very exposure to these asymmetries has the potential to increase self-reflexivity and eventually introduce slippages in the hegemonic mirror game of othering and identification.

\section{-Beyond 'the West' and 'THE EAst'?}

The doubling or monstrous repetition of oneself produced by the Japanese mimicry of 'the West' and 'Italy' exemplifies the ambivalent potential of Italian transnational spaces permeated by the uncanny dialectic between familiarity and unfamiliarity. This emotional geography is often sustained by a narcissistic lure that is mutually configured by both sides participating in the mirror game, nurturing the very root of the psychological economy of Occidentalism. But it can also be experienced as a threat of cognitive dissonance and alienation. Lastly, it can offer the potential for an empowering 'double vision' that engenders self-reflexivity and new agency. 45

The imagined geography of modern Occidentalism's reproduction of reassuring effects in the geopolitical, geocultural and geoemotional structuring of the world has to a large extent relied upon the repression of its colonising, reifying and ultimately de-humanising impulses. This has been crucial to making its hegemony so effective and familiar, and to it being ultimately perceived as natural. In order to uncover and expose this repression, attention to more unnatural principles may help provide different alternatives.

A concluding-and tempting-proposal for further investigation, at least at the micro-level of subjective positionality, is provided by the very uncanny potential of monstrosity in mediating a more hybrid process of otherness and identification. 46 On one hand, the other can function as a deformed and confining monstrous mirror: a projection of all that is most feared or hated, from generic aversions and anxieties to more intimate desires and impulses. The reassuring, and ultimately static, effect of this othering mirror in terms of contrastive identity is guaranteed by the extreme distortion of the projections as a means of making one's own authoriality invisible. On the other hand, it is the embodied and mutual exposure to the looking glass that is involved in the direct experience of transnational spaces which fosters the deforming and cross-cutting potential of monstrosity. This implies a critical 
recognition of oneself in the monstrous mirror, including all of the repressed projections that have mutually shaped the contours of the past identities of all of the actors involved in this process. Self-recognition and self-reflexivity may trigger the transforming and metamorphosic principle of monstrosity, leading to an open and transcultural identification, a more creative future that has yet to arrive:

A future that would not be monstrous would not be a future; it would already be a predictable, calculable, and programmable tomorrow. All experience open to the future is prepared or prepares itself to welcome the monstrous arrivant, to welcome it, that is, to accord hospitality to that which is absolutely foreign or strange, but also, one must add, to try to domesticate it, that is to make it part of the household and have it assume the habits, to make us assume new habits. This is the movement of culture. ${ }^{47}$

Toshio Miyake is a Marie Curie International Incoming Fellow at Ca' Foscari University of Venice (Department of Asian and North African Studies). His main research interests lie in Occidentalism, Orientalism and self-Orientalism relating to issues of hegemony, nation, whiteness, gender and youth. He has published a monograph on representations of 'the West' and 'Italy' in Japan titled Occidentalismi (2010) and essays on trans/national identity, Japanese popular cultures (literature, manga, anime, youth subcultures) and cultural industries in relation to globalisation.

\footnotetext{
-NOTES

${ }^{1}$ NHK Broadcasting Culture Research Institute (ed.), Nihonjin no sukina mono (What Japanese People Like), Nihon hōsō shuppan kyōkai, Tokyo, 2008, pp. 113-16.

2 Toshio Miyake, 'Italy Made in Japan: Occidentalism, Orientalism and Self-Orientalism in Contemporary Japan', in New Perspectives in Italian Cultural Studies, vol. 1, ed. Graziella Parati Fairleigh Dickinson University Press, New York, 2012, pp. 195-214.
} 
${ }^{3}$ Marco Pellitteri, The Dragon and the Dazzle: Models, Strategies, and Identities of Japanese Imagination: A European Perspective, Tunué, Latina, 2010, p. 556.

4 Toshio Miyake, 'Mostri Made in Japan. Orientalismo e auto-Orientalismo nell'epoca della globalizzazione' ('Monsters Made in Japan: Orientalism and Self-Orientalism in the Age of Globalisation'), in Culture del Giappone contemporaneo, ed. Matteo Casari Tunué, Latina, 2011, pp. 16193.

5 In contrast to an overall decline in enrolment in Italian universities, students of Japanese studies have dramatically increased, even since the tragic earthquake, tsunami and nuclear accident in northeastern Japan in 2011. At Ca' Foscari University of Venice, the institution with which the author is affiliated, there are at present 1,871 undergraduate and graduate students of Japanese $(1,205$ as a first language). For an investigation of the Japanese pop cultures-inspired hybrid style displayed by Italian artist Simone Legno, see Emiko Okayama and Francesco Ricatti, 'Tokidoki, Cute and Sexy Fantasies between East and West: Contemporary Aesthetics for the Global Market', Portal: Journal of Multidisciplinary International Studies, vol. 5, no. 2, 2008, pp. 1-23.

6 This study is part of a broader research project entitled 'Beyond "the West" and "the East":

Occidentalism, Orientalism and Self-Orientalism in Italy-Japan Relations', which has been made possible by a European FP 7-Marie Curie International Incoming Fellowship at Ca' Foscari University of Venice (2011-13).

7 Intersectionality has been theorised since the late 1980s by feminist sociologists in the United States as a means of highlighting how the axes of identity are not limited to one single level, but instead interact on multiple and interdependent levels, contributing cumulatively to systematic social inequality, as in the case of Afro-American women. See Kimberlé W. Crenshaw, 'Mapping the Margins: Intersectionality, Identity Politics, and Violence against Women of Color', Stanford Law Review, vol. 43, no. 6, 1991, pp. 1241-99.

8 Stuart Hall, 'The West and the Rest: Discourse and Power', in Formations of Modernity, ed. Stuart Hall and Bram Gieben, Polity Press, Cambridge, 1992, pp. 275-333; Fernando Coronil, 'Beyond Occidentalism: Toward Nonimperial Geohistorical Categories', Cultural Anthropology, vol. 11, no. 1, 1996, pp. 51-87; Toshio Miyake, Occidentalismi: La narrativa storica giapponese (Occidentalisms: Historical Narrative in Japan), Cafoscarina, Venezia, 2010.

9 Edward W. Said, Orientalism, Vintage, New York, 1978; Antonio Gramsci, Quaderni del carcere, ed. Valentino Gerratana, Einaudi, Turin, 1975.

10 Gramsci, pp. 1419-20. English translation from Antonio Gramsci, Gramsci: Prison Notebooks, trans. Joseph A. Buttigieg, Volume III, Columbia University Press, New York, 2010, p. 176.

11 Stuart Hall, 'The Whites in Their Eyes: Racist Ideology and the Media', in The Media Reader, eds Manual Alvarado and John O. Thompson, British Film Institute, London, 1990, pp. 7-23. 
12 Kōichi Iwabuchi, 'Complicit Exoticism: Japan and its Other', Continuum, vol. 8, no. 2, 1994, pp. 49-82; Kang Sang-jung, Orientarizumu no kanata e (Beyond Orientalism), Iwanami Shoten, Tokyo, 1996; Stefan Tanaka, Japan's Orient: Rendering Pasts into History, University of California Press, Berkeley, 1993.

13 Naoki Sakai, 'The West', in Encyclopedia of Contemporary Japanese Culture, ed. Sandra Buckley, Routledge, London and New York, 2002, p. 564.

${ }^{14}$ For the most comprehensive collection of essays regarding historical relations between Italy and Japan, see Adolfo Tamburello (ed.), Italia-Giappone 450 anni, 2 vols., Isiao-Iuo, Rome and Naples, 2003.

15 John Agnew, 'The Myth of Backward Italy in Modern Europe', in Revisioning Italy: National Identity and Global Culture, ed. Beverly Allen and Mary Russo, University of Minnesota Press, Minneapolis and London, 1997, pp. 23-42.

16 Cesere De Seta, 'L'Italia nello specchio del “Grand Tour”', in Storia d'Italia. Vol. 5, Il paesaggio, ed. C. De Seta, Einaudi, Turin, 1982, pp. 125-263.

17 Natsume Sōseki, Sōseki zenshū (The Complete Works of Sōseki), Vol. 13, Iwanami shoten, Tokyo, 1966, p. 30. English translation from Donald Keene, Modern Japanese Diaries, Henry Holt and Company, New York, 1995, p. 219.

18 Naoko Shimazu, Japan, Race and Equality: The Racial Equality Proposal of 1919, Routledge, London, 1998; Eiji Oguma, A Genealogy of 'Japanese' Self-Images, Trans Pacific Press, Melbourne, 2002 (1995). ${ }^{19}$ For instance, neo-Pop artist Takashi Murakami (b. 1962), at present the most celebrated Japanese artist on the international stage, has been able to spectacularise the uncanny ambivalence of Occidentalism and strategically turn it into his own aesthetic manifesto: 'We are deformed monsters. We were discriminated against as "less than humans" in the eyes of the "humans" of the West ... The Superflat project is our "Monster Manifesto", and now more than ever, we must pride ourselves on our art, the work of monsters'. Takashi Murakami, 'Superflat Trilogy: Greetings, You Are Alive', in Little Boy: The Arts of Japan's Exploding Subculture, ed. T. Murakami, Yale University Press, London, 2005, p. 161. 20 Keene, p. 217.

21 The survey was conducted by journalist Ichirō Enokido with sixty respondents who were asked to name the stupidest people in the world and the reasons for their choice (Dime, 6 November 1986). It was met by harsh protest from both the Italian Embassy in Tokyo and the Japanese Ministry of Foreign Affairs.

22 Survey commissioned from the agency NetRatings and based on answers from 5,000 respondents. See Pio D'Emilia, 'Mad for Italy', in Viste dalla Camera, ed. Italian Chamber of Commerce, special edition, June/July 2006, pp. 33-43.

23 The survey was conducted in 2007 and involved a total of 3,600 respondents who were sixteen years of age or older. Italy ranked first as a whole among female respondents. Among the male respondents, Italy ranked first in the 16-29 age group, third in the 30-59 age group and seventh in the over-60 age 
group. NHK Broadcasting Culture Research Institute (ed.), Nihonjin no sukina mono (What Japanese People Like), Nihon hōsō shuppan kyōkai, Tokyo, 2008, pp. 113-16.

24 Brand Databank and Nikkei Design (eds), Sanmannin no shōhi: sedai x seibetsu x burando de kiru (Consumption of 30,000 Persons by Age, Gender and Brand), NikkeiBPsha, Tokyo, 2009, pp. 196-201. It should be noted that the top ranking desire to travel to Italy is not equivalent to real travel, which is conditioned by financial, working and family criteria. In 2002, Italy as a real travel destination ranked sixth $(849,000)$, far behind the top-ranked United States $(5,896,000)$. See Japanese Ministry of Land, Infrastructure, Transport and Tourism (ed.), Kankō hakusho 2004 (White Paper on Tourism 2004), Kokuritsu insatsukyoku, 2004, Tokyo, p. 9.

25 Katarzyna J. Cwiertka, Modern Japanese Cuisine: Food, Power and National Identity, Reaktion Books, University of Chicago Press, London, 2006, p. 165.

${ }^{26}$ For investigation of the emergence of women as a paid labour force and consumers in relation to the tranforming mediascape in 1980s and 1990s Japan, see Lise Skov and Brian Moeran (eds), Women, Media and Consumption in Japan, Curzon Press, Surrey, UK and University of Hawai'i Press, Honolulu, 1995.

27 Dario Lolli, 'Orientalizing Football: The Transnational Experience of Nakata Hidetoshi', MA thesis, Birkbeck College, University of London, London, 2009.

${ }^{28}$ Chris Betros, 'Italian Dressing: Fashion and Food make Girolamo Panzetta One of Japan's Most Famous Italians', Metropolis, no. 710, 2 November 2007,

<http://archive.metropolis.co.jp/tokyo/710/faces.asp>, accessed 20 April 2010.

${ }^{29}$ For an investigation of images of Italy in Japanese literature, including the work of Nanami Shiono (b. 1937), the most popular, prolific and authoritative Japanese writer on Italy, see Toshio Miyake, Occidentalismi: La narrativa storica giapponese (Occidentalisms: Historical Narrative in Japan), Cafoscarina, Venice, 2010, pp. 117-246.

${ }^{30}$ See <http://www.comune.jp/>.

31 See http://www.venusfort.co.jp/multi/index_e.html>.

32 See <http://tabelog.com/italian/>; <http://tabelog.com/italian/tokyo/> (in Japanese; accessed 10 November 2012).

33 Rossella Ceccarini, Pizza and Pizza Chefs in Japan: A Case of Culinary Globalization, Brill, Leiden and Boston, 2011.

34 For the film's neo-Orientalism, see Homay King, Lost in Translation: Orientalism, Cinema, and the Enigmatic Signifier, Duke University Press, Durham, 2010, pp. 138-70.

35 This final section on the lived experience of Italians relies to some extent on the author's own experience as a teacher of Japanese studies at four different Italian universities from 2003 to 2008 and 2010 to 2011, as well as participant observation and almost daily conversation with Italian travellers, students and migrants in contemporary Japan from 2008 to 2010. 
${ }^{36}$ See the website of the Japanese Ministry of Justice, <http://www.estat.go.jp/SG1/estat/List.do?lid=000001089591> (in Japanese, accessed 10 November 2012).

37 See <http://tabelog.com/italian/>; <http://tabelog.com/italian/tokyo/> (in Japanese; accessed 10 November 2012)

38 I owe this provisional subdivision to informal talks with Alessandro Mantelli, a former graduate student of Japanese studies in Italy who has worked as a game localisation operator and information systems analyst for different Japanese companies in Tokyo (1999-2006).

39 The original Italian post uses the phrase 'mettere le mani nella marmellata', which literally translates as 'to put one's hands in the jam jar', or 'taste the jam', a common expression used to refer to something a child has been forbidden to do but does anyway. In this context it means to have sex with female students, which is forbidden by the rules of most language schools in Japan.

40 See <http://giappopazzie.blogspot.it/2009/07/insegnamento.html> (in Italian; accessed 11 November 2012).

${ }^{41}$ For a more detailed ethnography of gendered positionality and the dis/conjunctions between male English-language instructors and female students in Japan, see Keiron Bailey, 'Akogare, Ideology, and “Charisma Man” Mythology: Reflections on Ethnographic Research in English Language Schools in Japan', Gender, Place and Culture, vol. 14, no. 5, October 2007, pp. 585-608.

42 Summary of a two-hour interview via Skype (Venice-Tokyo) on 11 November 2012.

43 Ibid.

44 Summary of a two-hour interview in Venice on 2 November 2012.

45 For the 'migrant's double vision', see Homi K. Bhabha, The Location of Culture, Routledge, London, 1994 , p. 5.

46 See Miyake, 'Mostri Made in Japan'.

47 Jacques Derrida, 'Passages-From Traumatism to Promise', in Points: Interviews 1974-1994, ed. Elizabeth Weber, Stanford University Press, Stanford, 1995, p. 387. 